\title{
Nonlinear Relationship Between Working Capital and Firm Performance Moderated by Financial Constraints on Manufacture Firms Listed in Indonesia Stock Exchange
}

\author{
Azizah Rarasati Widhyadji, Farah Margaretha Leon* \\ Faculty of Economics and Business \\ Trisakti University \\ Jakarta, Indonesia \\ *farahmargaretha@trisakti.ac.id
}

\begin{abstract}
The research aims to analyze the relationship between the working capital and firm performance of manufacturing companies listed in Indonesia stock exchange (IDX). Data were obtained from 33 manufactured from 2014 to 2018 using the Eviews 9.0 multiple regression analysis methods. The outcome showed the existence of a nonlinear relationship between both parties, which applies to the rise of financial constraints. Therefore, an increase in working capital helps firms to raise their sales till a certain optimal point is achieved. It also raises cost and risks of bankruptcy. This study, therefore, provides evidence of the nonlinear relationship between working capital management and firm performance of manufactured firms listed in the IDX.
\end{abstract}

Keywords-financial constraints, firm performance, working capital, net trade cycle

\section{INTRODUCTION}

Profitability is a relationship between revenues and cost, leading to the use of current or fixed assets by firms in productive activities [1]. Efficient working capital management aims to avoid excessive investment in assets and maintain a company's ability to determine the balance amid liquidity and profitability [2]. High investment in working capital has the ability to help companies increase sales, obtain a higher discount for early payments, and raise their value [3]. However, an excess investment in working capital leads to a few unwanted impacts with the ability to harm the value of shareholders [3]. This is because excess investment needs adequate financing and thereby, increasing the probability of bankruptcy [4]. These two views create a perspective that proves the existence of a tradeoff between benefits and costs for every level.

In 2018, Bank of Indonesia reported that the Prompt Manufacturing Index (PMI) was on the third quartile with $52.02 \%$. The percentage beyond 50 showed that manufacture sectors were going through an expansion phase due to the increase in production volume with a positive impact in the domestic market. Some previous studies stated is the possibility of a nonlinear relationship between the investment level of working capital with the firm's profitability, thereby encouraging them to maximize their performance [5]. Therefore, maximizing the stock value of firms at an optimal level tends to improve their performance [3]. According to the studies carried out by a few researchers, there are inconsistencies associated with the working capital management effects on firm performance [6,7]. Hence, the result can be linear/quadratic and positive/negative, depending on the relevant variable and situations. In addition, previous studies majority focused on the linear relationship of firm performance [8-10]. Meanwhile, Baños-Caballero et al., [11], Simon et al., [12], and Afrifa [13] stated that failed to examine the nonlinear relationship between these parties. A research carried out in China, examined the nonlinear relationship using financial constraints [14]. However, according to Charitou, no research has been conducted with the firm's profitability using data from Indonesia [15].

\section{LITERATURE REVIEW}

According to numerous studies, working capital management affects profitability, liquidity, value, and corporate performance significantly [3]. Therefore, it is important to manage current assets and liabilities efficiently in order to reduce the risk associated with the inability to meet the companies' short-term obligations by avoiding excess investment [16], which eventually tends to affect profitability. Simon [12] et al., Afrifa [13], Pais and Gama [17], and Mun and Jang [18], stated that there is the existence of a nonlinear relationship between working capital and profitability. Furthermore, corporate performance increases by maintaining an optimum level and decreases with an increase in the working capital. Therefore, firms have to maintain an optimum 
level by keeping a balance between costs and its beneficial values. In accordance with these descriptions, the following was formed:

H1: There is a nonlinear relationship between working capital and corporate performance, which is positive at a low level and vice versa.

A firm easily gains external financing without any obstacles with the non-existence of market imperfections. Therefore, they do not always have to depend on the availability of internal financing. According to Chauhan and Banerjee [19], these kinds of situations are almost impossible in reality, because investment decision is affected by the constraint and availability of external financing. They also stated that firms try to reduce their production cost by optimizing its working capital level and increasing the availability of internal financing for investment projects. In addition, working capital is affected by the financial needs of a firm, therefore, it is a significant way to affect its behavior [20]. Firms with a high capability of internal financing have more access to the capital market [21]. According to these descriptions, the following hypothesis is formed:
$\mathrm{H}_{2}$ : There is a positive relationship between working capital and corporate performance at a low investment level.

\section{METHODS}

This research uses secondary data obtained from libraries, documentary, and financial reports published in intermediary media such as the idx.co.id and www.sahamok.com obtained from 2014 till 2018. A total of 162 companies were listed in IDX, however, amongst them, 44 companies failed to publish its financial report, while approximately 27 companies used different currency in its financial report. Furthermore, 58 companies did not pay dividends continuously, therefore, after performing purposive sampling, only 33 companies met the criteria for this research. The data in this research were tested using Eviews, with the multiple regression method used to determine the relationship between independent and dependent variables, asset size, financial leverage, growth, and operating cash flows. The measurement for each variable is shown in table 1 as follows:

TABLE I. VARIABLE AND MEASUREMENT

\begin{tabular}{|c|c|c|c|}
\hline Variable & Proxy & Measurement & References \\
\hline \multicolumn{4}{|c|}{ Dependent } \\
\hline \multirow[t]{4}{*}{ Firm Performance } & ROA & Earnings Before Interest and Taxes & \multirow[t]{2}{*}{ [14] } \\
\hline & & Total Asset & \\
\hline & \multirow[t]{2}{*}{ TOBINS'S Q } & $\begin{array}{c}\text { Market value of equity + Book value of total asset - } \\
\text { Book value of equity }\end{array}$ & \multirow[t]{2}{*}{ [13] } \\
\hline & & Book value of the total asset & \\
\hline \multicolumn{4}{|c|}{ Independent } \\
\hline \multirow[t]{2}{*}{ Working Capital } & NET & $\begin{array}{lcccc}\text { (Account } & \text { Receivables/Sales) } & \text { x } & 365 & + \\
\text { (Inventories/Sales) x } & 365-\text { (Account payable/Sales) } & \text { x } \\
365 & & & & \end{array}$ & [14] \\
\hline & NET2 & $\begin{array}{lcccc}{[(\text { Account }} & \text { Receivables/Sales) } & \text { x } & 365 & + \\
\text { (Inventories/Sales) x } & 365-(\text { Account } & \text { payable/Sales) } & \text { x } \\
365] 2 & & & & \end{array}$ & [14] \\
\hline \multicolumn{4}{|c|}{ Control } \\
\hline Asset Size & AS & Log (Total asset) & [14] \\
\hline \multirow[t]{2}{*}{ Financial Leverage } & FL & Total Debt & \multirow[t]{2}{*}{ [14] } \\
\hline & & Total Asset & \\
\hline Growth & $\mathrm{Gr}$ & $\frac{\text { Sales this year }- \text { Sales previous year }}{\text { Sales previous year }}$ & [14] \\
\hline \multirow[t]{2}{*}{ Operating Cash Flows } & \multirow[t]{2}{*}{$\mathrm{OCF}$} & $\begin{array}{c}\text { Operating income before depreciation and amortization } \\
\text { - interest expense - income tax expense }\end{array}$ & \multirow[t]{2}{*}{ [14] } \\
\hline & & $\begin{array}{c}\text { Total Asset } \\
\end{array}$ & \\
\hline \multicolumn{4}{|c|}{ Moderating } \\
\hline \multicolumn{4}{|c|}{ Financial Constraints } \\
\hline \multirow[t]{2}{*}{ Cash Flow } & $\mathrm{CF}$ & $\begin{array}{c}\text { Earnings Before Interest and Tax } \\
\text { + Depreciation }\end{array}$ & \multirow[t]{2}{*}{ [11] } \\
\hline & & Total Assets & \\
\hline \multirow{2}{*}{$\begin{array}{l}\text { Cost Of External } \\
\text { Finance }\end{array}$} & \multirow[t]{2}{*}{ EFC } & Financial Expenses & \multirow[t]{2}{*}{ [11] } \\
\hline & & Total Debt & \\
\hline
\end{tabular}


Table 1. Cont.

\begin{tabular}{|l|l|c|l|}
\hline Dividend Payout Ratio & DPR & Dividends & {$[11]$} \\
\hline Interest Coverage Ratio & ICR & Net Profit & \\
& & Earnings Before Interest and Tax & \\
\cline { 2 - 4 } & & Financial Expense & \\
\hline Sales Size & SS & Log (Total Sales) & {$[11]$} \\
\hline
\end{tabular}

\section{RESULTS AND DISCUSSION}

The result of table 2 shows an insignificant effect on working capital as measured by the Net Trade Cycle and its square on measuring firm performance, return on assets (ROA), and Tobin's Q with positive and negative coefficients. This shows an indirect relationship between these two variables [14].

The results of Table 2 also show that financial leverage has no significant and insignificant effect on return on assets
(ROA) and Tobin's Q, respectively. These results are not in accordance with the research of Laghari and Chengang [14], which stated that financial leverage has a negative and positive effect on both variables. This study also used operating cash flow as a control variable, which has a negative and positive significant effect on these variables. This is in accordance with the study conducted by Laghari and Chengang [14], which stated that operating cash flow has a significant positive effect on Tobin's Q, and none on ROA.

TABLE II. TEST RESULTS OF HYPOTHESIS 1

\begin{tabular}{|l|l|l|l|l|l|l|l|}
\hline \multicolumn{4}{|c|}{ Eq. 1 ROA } & \multicolumn{1}{c|}{ Eq. 12 Tobin's Q } \\
\hline \multicolumn{1}{|c|}{ Variable } & \multicolumn{1}{|c|}{ Coef. } & \multicolumn{1}{|c|}{ Sig. } & \multicolumn{1}{c|}{ Desc. } & \multicolumn{1}{c|}{ Variable } & \multicolumn{1}{c|}{ Coef } & \multicolumn{1}{c|}{ Sig. } & Desc. \\
\hline C & -0.1195 & 0.0123 & - & C & -24.6477 & 0.0000 & - \\
\hline NET & 0.0003 & 0.1050 & Insignificant & NET & 0.0381 & 0.1347 & Insignificant \\
\hline NET2 & $-1.62 \mathrm{E}-06$ & 0.0782 & Insignificant & NET2 & -0.0002 & 0.1217 & Insignificant \\
\hline TQ & 0.0005 & 0.0327 & significant & TQ & 0.7817 & 0.0000 & significant \\
\hline ROA & 0.6697 & 0.0000 & significant & ROA & 20.2392 & 0.0001 & significant \\
\hline OCF & -0.1615 & 0.0071 & significant & OCF & 16.3257 & 0.0234 & significant \\
\hline FL & -0.0126 & 0.5028 & Insignificant & FL & -1.3281 & 0.5492 & Insignificant \\
\hline Gr & 0.0869 & 0.0000 & significant & Gr & 6.5984 & 0.0084 & significant \\
\hline Asset size & -0.0559 & 0.0010 & significant & Asset size & -1.5123 & 0.4388 & Insignificant \\
\hline
\end{tabular}

According to table 3, when the working capital is measured by Net Trade cycle, its square is moderated by financial constraints and cash flow, with a significant effect and nonlinear relationship on ROA and Tobin's Q [14]. However, the different directions on the Net Trade Cycle and its square show a nonlinear relationship between working capital investment and firm performance when moderated with the cost of external finance [14].

This research is also similar to the study carried out by Laghari and Chengang [14] where the Net Trade Cycle and its square showed significant and insignificant effects on ROA and Tobin's Q, in accordance with its dividend payout ratio. Table 3 also shows an insignificant effect on both variables with a nonlinear relationship in accordance with the research conducted by Laghari and Chengang [14]. This research also shows that when working capital was measured with moderation from financial constraints, the size of its sales has a significant and insignificant effect. The existence of opposite directions on their working capital shows that there is also a nonlinear relationship between the size and performance of the sale of a company, as stated by Laghari and Chengang [14].

TABLE III. TEST RESULTS OF HYPOTHESIS 2

\begin{tabular}{|c|c|c|c|c|c|c|c|}
\hline \multicolumn{4}{|c|}{ Model 2 ROA } & \multicolumn{4}{|c|}{ Model 7 Tobin's Q } \\
\hline Variable & Coef. & Sig. & Desc. & Variable & Coef & Sig. & Desc \\
\hline $\mathrm{C}$ & -0.0647 & 0.2039 & - & $\mathrm{C}$ & -19.5114 & 0.0010 & - \\
\hline CF*NET & -0.0055 & 0.0000 & Significant & CF*NET & 0.1892 & 0.1687 & Insignificant \\
\hline $\mathrm{CF}^{*} \mathrm{NET}^{2}$ & $2.64 \mathrm{E}-05$ & 0.0000 & significant & $\mathrm{CF}^{*} \mathrm{NET}^{2}$ & -0.0006 & 0.3718 & Insignificant \\
\hline \multicolumn{4}{|c|}{ Model 3 ROA } & \multicolumn{4}{|c|}{ Model 8 Tobin's Q } \\
\hline Variable & Coef. & Sig. & Desc. & Variable & Coef. & Sig. & Desc. \\
\hline $\mathrm{C}$ & -0.0348 & 0.4871 & - & $\mathrm{C}$ & -22.8753 & 0.0003 & - \\
\hline EFC*NET & -0.0022 & 0.8233 & Insignificant & EFC*NET & 0.6568 & 0.5878 & Insignificant \\
\hline
\end{tabular}


Table 3. Cont.

\begin{tabular}{|c|c|c|c|c|c|c|c|}
\hline $\mathrm{EFC}^{*} \mathrm{NET}^{2}$ & $3.39 \mathrm{E}-05$ & 0.4127 & Insignificant & $\mathrm{EFC}^{*} \mathrm{NET}^{2}$ & -0.0030 & 0.5602 & Insignificant \\
\hline \multicolumn{4}{|c|}{ Model 4 ROA } & \multicolumn{4}{|c|}{ Model 9 Tobin's Q } \\
\hline Variable & Coef. & Sig. & Desc. & Variable & Coef. & Sig. & Desc. \\
\hline $\mathrm{C}$ & -0.0873 & 0.0841 & - & $\mathrm{C}$ & -16.6647 & 0.0037 & - \\
\hline DPR*NET & 0.0011 & 0.0040 & Significant & DPR*NET & $\begin{array}{l}-0.0286 \\
\end{array}$ & 0.5060 & Insignificant \\
\hline DPR*NET2 & $-5.25 \mathrm{E}-06$ & 0.0075 & significant & DPR*NET2 & $7.30 \mathrm{E}-05$ & 0.7414 & Insignificant \\
\hline \multicolumn{4}{|c|}{ Model 5 ROA } & \multicolumn{4}{|c|}{ Model 10 Tobin's Q } \\
\hline Variable & Coef. & Sig. & Desc. & Variable & Coef. & Sig. & Desc. \\
\hline $\mathrm{C}$ & $\begin{array}{l}-0.0692 \\
\end{array}$ & 0.1588 & - & $\mathrm{C}$ & -13.5530 & 0.0165 & - \\
\hline ICR*NET & 2.83E-06 & 0.3930 & Insignificant & ICR*NET & 0.0003 & 0.3963 & Insignificant \\
\hline ICR*NET2 & $-2.11 \mathrm{E}-08$ & 0.2867 & Insignificant & ICR*NET2 & $-2.29 \mathrm{E}-06$ & 0.3114 & Insignificant \\
\hline \multicolumn{4}{|c|}{ Model 6 ROA } & \multicolumn{4}{|c|}{ Model 11 Tobin's Q } \\
\hline Variable & Coef. & Sig. & Desc. & Variable & Coef. & Sig. & Desc. \\
\hline $\mathrm{C}$ & -0.6524 & 0.0000 & - & $\mathrm{C}$ & 1.7112 & 0.9214 & - \\
\hline Sales size*NET & $\begin{array}{l}-0.0009 \\
\end{array}$ & 0.0004 & Significant & Sales size*NET & 0.0188 & 0.4992 & Insignificant \\
\hline${\text { Sales size* }{ }^{*} \mathrm{NET}^{2}}^{2}$ & $3.70 \mathrm{E}-06$ & 0.0004 & significant & Sales size*NET $^{2}$ & $-9.54 \mathrm{E}-05$ & 0.4272 & Insignificant \\
\hline
\end{tabular}

\section{CONCLUSION}

In conclusion, the working capital investment, which is measured with the Net Trade cycle and its square, has a nonlinear relationship with firm performance in accordance with the ROA and Tobin's Q. Therefore, an increase leads to a rise in firm performance till its optimal point. However, a rise beyond this point, leads to a decrease in firm performance, due to additional costs incurred by the company to maintain and monitor its working capital. Therefore, firms tend to use this research as a reference to pay more attention to their investment in order to anticipate and high performance. In addition, the result has the ability to help investors in considering and reviewing firm performance to avoid bankruptcy and waste of resources.

\section{REFERENCES}

[1] F. Margaretha, F. Ekonomi, and U. Trisakti, "Pengaruh Manajemen Modal Kerja Dan Menengah Di Indonesia," Bisnis Dan Akunt., vol. 18, no. 1, pp. 11-24, 2016.

[2] I. Dalci, C. Tanova, H. Ozyapici, and M. A. Bein, "The Moderating Impact of Firm Size on the Relationship between Working Capital Management and Profitability," Prague Econ. Pap., vol. 28, no. 3, pp. 296-312, 2019

[3] N. Aktas, E. Croci, and D. Petmezas, "Is working capital management value-enhancing? Evidence from firm performance and investments," J. Corp. Financ., vol. 30, no. 1, pp. 98-113, 2015.

[4] R. Kieschnick, M. Laplante, and R. Moussawi, "Working capital management and shareholders' wealth," Rev. Financ., vol. 17, no. 5, pp. $1827-1852,2013$

[5] D. F. N. Gomes, "How does Working Capital Management affect Firms' Profitability? - Evidence from Portugal," Mestr. Financ. Lisboa Sch. Econ. Manag., 2013.

[6] E. Mansoori, "I NTERDISCIPLINARY J OURNAL O $\mathrm{F}$ C ONTEMPORARY R ESEARCH I N B USINESS THE EFFECT OF W ORKING CAPITAL MANAGEMENT ON FIRM , S PROFITABILITY :," pp. 472-486, 2012.

[7] D. Yazdanfar and P. Öhman, "The impact of cash conversion cycle on firm profitability,” Int. J. Manag. Financ., vol. 10, no. 4, pp. 442-452, 2014.
[8] J. U. Madugba and A. K. Ogbonnaya, "Working Capital Management and Financial Performance: Evidence from Manufacturing companies in Nigeria," Rev. Bras. Ergon., vol. 9, no. 2, p. 10, 2016.

[9] T. Bagh, M. I. Nazir, M. A. Khan, M. A. Khan, and S. Razzaq, "The impact of working capital management on firms financial performance: Evidence from Pakistan,” Int. J. Econ. Financ. Issues, vol. 6, no. 3, pp. 1097-1105, 2016

[10] B. Abuzayed, "Working capital management and firms' performance in emerging markets: The case of Jordan,” Int. J. Manag. Financ., vol. 8, no. 2, pp. 155-179, 2012.

[11] S. Baños-Caballero, P. J. García-Teruel, and P. Martínez-Solano, "Working capital management, corporate performance, and financial constraints,” J. Bus. Res., vol. 67, no. 3, pp. 332-338, 2014.

[12] S. Simon, N. Sawandi, and M. A. Abdul-Hamid, "The quadratic relationship between working capital management and firm performance: Evidence from the Nigerian economy," J. Bus. Retail Manag. Res., vol. 12, no. 01, 2017.

[13] G. A. Afrifa, "Net working capital, cash flow and performance of UK SMEs," Rev. Account. Financ., vol. 15, no. 1, pp. 21-44, 2016.

[14] F. Laghari and Y. Chengang, "Investment in working capital and financial constraints: Empirical evidence on corporate performance," Int J. Manag. Financ., vol. 15, no. 2, pp. 164-190, 2019.

[15] M. Charitou, P. Lois, and H. B. Santoso, "The Relationship Between Working Capital Management And Firms Profitability: An Empirical Investigation For An Emerging Asian Country,” Int. Bus. Econ. Res. J., vol. 11 , no. 8, p. 839, 2016.

[16] S. Wasiuzzaman, "Working capital and firm value in an emerging market,” Int. J. Manag. Financ., vol. 11, no. 1, pp. 60-79, 2015.

[17] M. A. Pais and P. M. Gama, "Working capital management and SMEs profitability: Portuguese evidence,” Int. J. Manag. Financ., vol. 11, no. 3, pp. 341-358, 2015.

[18] S. G. Mun and S. C. S. Jang, "Working capital, cash holding, and profitability of restaurant firms," Int. J. Hosp. Manag., vol. 48, pp. 1-11, 2015.

[19] G. S. Chauhan and P. Banerjee, "Financial constraints and optimal working capital - evidence from an emerging market," Int. J. Manag. Financ., vol. 14, no. 1, pp. 37-53, 2018.

[20] R. C. Chan, "Financial Constraints, Working Capital and the Dynamic Behavior of the Firm," SSRN Electron. J., pp. 1-33, 2012.

[21] M. D. Hill, G. W. Kelly, and M. J. Highfield, "Matthew D. Hill, G Wayne Kelly, and Michael J. Highfield*.pdf," no. 1992, pp. 783-805, 2010. 